https://dx.doi.org/10.4314/ijs.v19i2.14

Ife Journal of Science vol. 19, no. 2 (2017)

\title{
BIOSORPTION OF LEAD (II) ION USING Penicillium citrinum KR706304 ISOLATED FROM THE MANGROVE SOIL ENVIRONMENT OF SOUTHEAST BORNEO.
}

\author{
${ }^{1,3}$ Wahab, A. A.*, ${ }^{1}$ Awang, A. S. A. H., ${ }^{1}$ Azham, Z., ${ }^{2}$ Tay, M. G. and ${ }^{3}$ Adeyemi, F. M. \\ ${ }^{1}$ Department of Molecular Biology, ${ }^{2}$ Department of Chemistry, Faculty of Resource Science and Technology,Universiti \\ Malaysia Sarawak, 94300 Kota Samarahan, Sarawak, Malaysia. \\ ${ }^{3}$ Department of Biological Sciences, Faculty of Basic and Applied Sciences, Osun State University, P.M.B 4494, Osogbo, \\ Nigeria. \\ *Corresponding author email/phone no: abideen.wahab@uniosun.edu.ng/+2348034588086 \\ Alternative email:abidec1430@yahoo.com \\ (Received: Accepted:)
}

\section{ABSTRACT}

\begin{abstract}
The use of biological entities (fungi, bacteria, and algae) is considered to be a potential cost-effective and environmental friendly technique for heavy metals pollution sequestration. The present study aimed to isolate efficient lead tolerant fungi from mangrove soil environment and measure its capability for lead removal from aqueous solution.

Lead

tolerant fungal strains were isolated from soil samples using MEA (malt extract agar) amended with varied concentrations of lead ions (100-500 $\left.\mathrm{mg} \mathrm{l}^{-1}\right)$. The most tolerant fungal strain was successfully isolated and identified molecularly as Penicillium citrinum KR706304 The isolated fungus was used for biosorption studies using malt extract broth (MEB) amended with lead ions. The effects of $\mathrm{pH}$, temperature, initial metal concentration, biomass dose and age, agitation and contact time to the $\mathrm{Pb}$ (II) removal efficiency were monitored in the study.

The results showed that the lead removal was optimal at concentration of $400 \mathrm{mg}^{-1}$, maximum adsorption of $329 \pm 33.4 \mathrm{mg} \mathrm{g}^{-1}$ was observed at $\mathrm{pH} 7$ and temperature of $30^{\circ} \mathrm{C}$ during the batch biosorption experiments. The optimal parameters for biomass dose, agitation speed, contact time and biomass age were $0.04 \mathrm{gl}^{-1}, 150 \mathrm{rpm}, 60$ min and fifth day; respectively.

The study revealed that the isolated Penicillium citrinum KR706304 has the potential to be used as a biosorbent for heavy metals particularly $\mathrm{Pb}(\mathrm{II})$ removal from the contaminated sites.
\end{abstract}

Keywords: Fungi, Heavy metals, Lead(II) removal, Penicillium citrinum.

\section{INTRODUCTION}

Bioremediation is an alternative green technology comprising of various processes involved in the decontamination of environments already polluted by contaminants into its original status. The processes include, biosorption, bioaccummulation and bioaugmentaton (Abdulqawi, 2011). Biosorption is one of the processes of bioremediation in which metal ion adsorption by biomass occurs as a result of interactions with functional groups native proteins, lipids, and carbohydrates that make up the cell wall (Chen et al., 2007; Sana et al., 2015). The advantage of biosorption over conventional treatment methods is the low cost, environmental friendliness, and also often offers metal recovery and biomass regeneration (Volesky, 2007; Muñoz et al., 2015). The heavy metal ion biosorption by fungi is based mainly on two mechanisms: covalent bonding with functional groups including carboxyl, hydroxyl, phosphate, amino, sulphydryl, and the result of physico-chemical interactions directed by adsorption phenomena (Say et al., 2011).

Lead reaches the human body through drinking of affected water, inhaling polluted air particularly from automobiles, peeling of paints and through food chain via cereals, vegetables, fishes and meat (Abdulqawi, 2011). Lead is known for its high environmental impact and toxicity (Mason et al., 2014), and along with mercury and cadmium, is considered one of "the big three" heavy metals in contaminated effluents (Volesky, 2007; Muñoz et al., 2015). The European Directive 2008/105/CE includes lead and its compounds in the list of priority substances in the environment quality standards; establishing a concentration of 0.0072 $\mathrm{mg} \mathrm{l}^{-1}$ as the maximum permissible in the case of surface water (Muñoz et al., 2015).

Fungi have been reported as an efficient economic source for the removal of toxic heavy metals from 
aqueous solution, because the fungal cell wall has different functional groups which are involved in metal binding, and that the fungi can be easily isolated from environment for metal biosorption purposes (Wang and Chen 2006; Iskandar et al., 2011). Among microbial biosorbents, fungal biomass are widely used in biosorption technology (Gupta et al., 2002; Zulkarnain et al., 2015). Previous reports by Li et al. (2008) showed the potentiality of Penicillium simplicissimum for $\mathrm{Pb}(\mathrm{II})$ and $\mathrm{Cu}(\mathrm{II})$ while Penicillium purpurogenum exhibits selectivity for $\mathrm{Pb}(\mathrm{II})$ over metals such as $\mathrm{Cd}(\mathrm{II}), \mathrm{Hg}$ (II) and $\mathrm{As}(\mathrm{II})$ (Say et al., 2003). In order to improve biosorption effectiveness, the identification of additional fungal strains with high metal sorption capacity is essential (Volesky, 2007; Kumar et al., 2014; Muñoz et al., 2015). Therefore, this study is aimed at isolating efficient lead tolerant fungi from mangrove soil environment and measure its capability for lead removal from aqueous solution.

\section{MATERIALS AND METHODS}

\section{Sampling and Isolation of Fungal Strain}

Soil samples were collected from mangrove soil environment at different locations in Asajaya region in the southeast Borneo, Sarawak, Malaysia and stored at $-20^{\circ} \mathrm{C}$. Lead solutions were prepared using lead acetate $\left\{\mathrm{Pb}\left(\mathrm{CH}_{3} \mathrm{COO}\right)_{2} \cdot 3 \mathrm{H}_{2} \mathrm{O}\right\}$ (Merck, Germany). The $\mathrm{pH}$ of the working solution was adjusted to $\mathrm{pH} 5.0$ using hydrochloric acid (3 M $\mathrm{HCl}$ ). Fresh dilutions were used for each biosorption experiments. Lead tolerant fungal strains were isolated from the soil samples using fungal medium (malt extract agar) amended with lead ions $\left(100-500 \mathrm{mgl}^{-1}\right)$.

Serial dilution techniques were performed to decrease the microbial load in the samples and a standard pour plate method was performed. The plates were then incubated at room temperature for $72 \mathrm{~h}$. After incubation, different morphological colonies from each plate were isolated and characterized for further use in subsequent heavy metal removal studies. The concentration of lead ions added to the medium was determined and measured using atomic absorption spectrometer (AAS) (Thermo Scientific iCE 3500, Japan).

\section{Preparation of Fungal Biomass as}

\section{Biosorbent Material}

Malt extract broth was used for the cultivation of isolated fungal strain, Penicillium citrinum KR706304 in Erlenmeyer flasks of $500 \mathrm{ml}$ volume with $250 \mathrm{ml}$ effective volume. The $\mathrm{pH}$ of the growth medium was maintained at 5.5 using $1 \mathrm{M}$ $\mathrm{HCl}$ and $1 \mathrm{M} \mathrm{NaOH}$. The flasks were closed with cotton plugs and covered with aluminium foil for autoclaving. After autoclaving, the media was cooled to $30^{\circ} \mathrm{C}$, and three mycelia plugs of $7 \mathrm{~mm}$ in diameter was used as an inoculum and incubated in an orbital rotary shaker (Taitec, BR43FL Japan) at $150 \mathrm{rpm}$ and $30^{\circ} \mathrm{C}$. After 7 days of incubation, the biomass was harvested from the growth medium by centrifugation for $10 \mathrm{~min}$ at $10,000 \mathrm{rpm}$ and filter paper $(90 \mathrm{~mm}$ size) was used for filtration for biomass collection. The residual growth medium was removed from the collected biomass through washing with distilled water. Then, the biomass was drained, dried at $60{ }^{\circ} \mathrm{C}$ for $24 \mathrm{~h}$, ground with a mortar and pestle before metal biosorption experiments, and stored at room temperature in a sealed bottle prior further use.

\section{Evaluation of Metal Uptake Capacity}

In order to evaluate the metal adsorption capacity and the percentage efficiency of the fungal strain, a mass balance equation (Equation 1) was used according to Akar et al. (2009):

$q=V(C i-C f) / W$

Where,

$$
\begin{gathered}
\mathrm{q}=\text { the adsorbed metal }\left(\mathrm{mg} \mathrm{g}^{-1}\right) \\
\mathrm{V}=\text { the volume of metal solution }(\mathrm{l}) \\
\mathrm{C} i=\text { initial metal concentration }\left(\mathrm{mg} \mathrm{l}^{-1}\right) \\
\mathrm{Cf}=\mathrm{final} / \text { residual concentration }\left(\mathrm{mg} \mathrm{l}^{-1}\right) \\
\mathrm{W}=\text { amount of biomass }\left(\mathrm{mg} \mathrm{l}^{-1}\right)
\end{gathered}
$$

The percentage biosorption of metal ion was determined using the methods of Sari and Tuzen (2009):

Biosorption $(\%)=(C i-C f) / C i \times 100$

\section{Optimization of Biosorption Experiments}

In each $100 \mathrm{ml}$ of Erlenmeyer flask, a volume of $0.04 \mathrm{~g}$ of the powdered biosorbent of Penicillium 
citrinum KR706304 was incubated for $3 \mathrm{~h}$ in $20 \mathrm{ml}$ of lead (II) solution $\left(50 \mathrm{mg} \mathrm{l}^{-1}\right)$ at $30{ }^{\circ} \mathrm{C}$ with shaking at $150 \mathrm{rpm}$. The biosorption experiment parameters were maintained throughout the experiments unless otherwise stated. After incubation, the fungal biomass was harvested and the residual lead was measured using Atomic Absorption Spectrometer (AAS). For each experiment a blank, containing the metal ions solution without any biosorbent and a control with distilled water (no metal ion added) and $0.04 \mathrm{~g}$ of biosorbent were set up. The effects of different physical parameters on lead removal, such as $\mathrm{pH}$, temperature, initial metal concentration, agitation, biomass dose, and contact time were studied.

\section{Scanning Electron Microscopy (SEM)}

Loaded and unloaded biomass of the fungal isolate with lead ions were treated with $6 \%$ glutaraldehyde, incubated overnight at $4{ }^{\circ} \mathrm{C}$ and washed 2-3 times with phosphate buffer. Dehydration was done with varied percentages of acetone. The samples were dried on CPD (critical point drying). The samples were mounted on a lead holder with a double stick tape followed by coating with a thin layer of gold under vacuum by Sputter coater. Then samples were viewed using scanning electron microscope (JOEL JXA-840A SEM, Japan).

\section{Statistical Analysis}

The values presented in the study were means of three replicates and expressed as means \pm standard deviation (SD). The Microsoft Office Excel (2010) was employed to calculate the standard deviation where needed. Results were analysed statistically amongst and between mean of data samples with variance analysis at 95\% level of confidence.

\section{RESULTS AND DISCUSSION \\ Isolation and Identification of Lead Tolerant Fungal Strain.}

In isolation experiments, the number of fungal colonies in plates reduced with an increase in lead concentration. This was related to the toxic nature of lead as a heavy metal, and tolerant nature of the fungi. The isolated fungal strain showed a maximum lead tolerance of $400 \mathrm{mg} \mathrm{l}^{-1}$. Morphological characterization of the isolated lead tolerant fungal strain was then done using conventional light microscopy. This was done using Lacto phenol cotton blue mounting with the pure culture of the isolated strain (Figure 1). Molecular identification of the fungal isolate further confirmed that these isolates were Penicillium species. A phylogenetic tree was constructed based on sequencing of the ITS1 and ITS 4 regions, and it can be seen that the branches of the tree were short, indicating little divergence of the ITS sequences between the isolates (Figure 2).

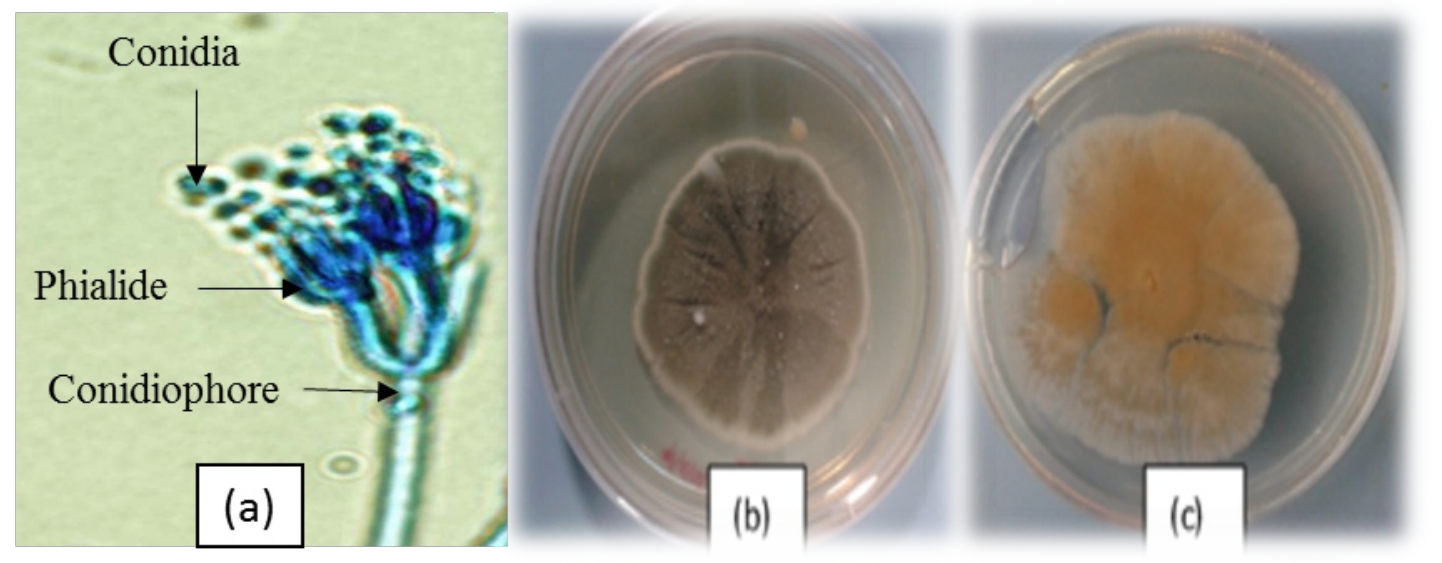

Figure 1: UMAS B2 grown on PDA after day 21, expected to be genus Penicillium. (a) Mass of conidia formed at the tip of a single long, flask-shaped phialide, septate hyphae (mag. 1000x). (b) Colony surface; colonies were slow growing with a dense greenish mycelial mat. Conidiation were noted on the greenish floccules, which later grew into white tufts. No pigmentation occurred. (c) Reverse colony surface; white with pale brownish mycelium, the brownish colour is the colour of the growth medium. UMAS B2 was the code for the isolate before molecular identification of the isolate. 


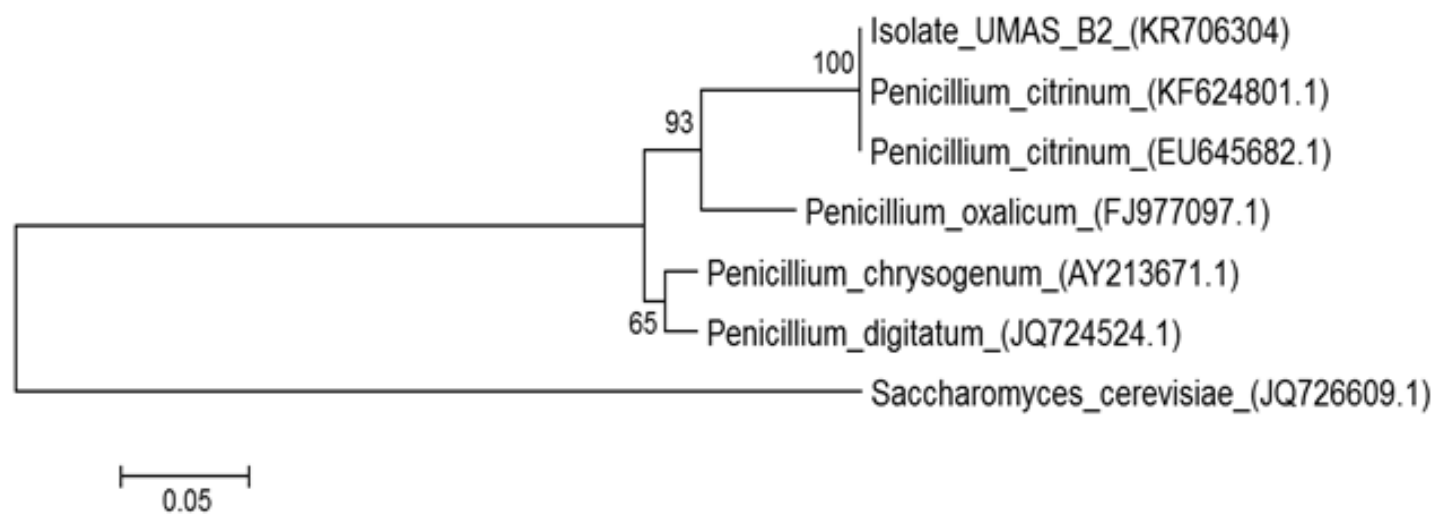

Figure 2: Neighbour-joining tree from ITS sequences showing the relationship between the isolated indigenous fungus UMAS B2 and other closely related Penicillium species retrieved from the GenBank (accession number). Bootstrap values $>70 \%$ (1000 replicates) are shown on the branches. Bar $=5$ nucleotide substitution per 100 nucleotides

\section{Effect of $\mathrm{pH}$ on Lead Biosorption}

Lead removal increases as $\mathrm{pH}$ increases in the metal solution up to $\mathrm{pH} 7$ and decreases thereafter (Figure 3). Baysal et al. (2009) found that the biosorption of lead (II) by Candida albicans was maximal at $\mathrm{pH} 5$, whereas it was at $\mathrm{pH} 7$ by Kluyveromyces marxianus immobilized in alginate beads (Subhashini et al., 2013).
Inhibition of lead (II) biosorption at low $\mathrm{pH}$ (less than 3) could be because of a net positive charge density on metal binding sites due to high concentrations of protons in the solution (Abdulqawi, 2011). In acidic medium, the fungal cell wall becomes highly protonated due to excess $\mathrm{H}^{+}$ions that binds to functional groups (-OH, $\mathrm{NH}_{2},-\mathrm{NH}$, and $-\mathrm{C}=\mathrm{O}$ ) (Bennett et al., 2013; De Sotto et al., 2015).

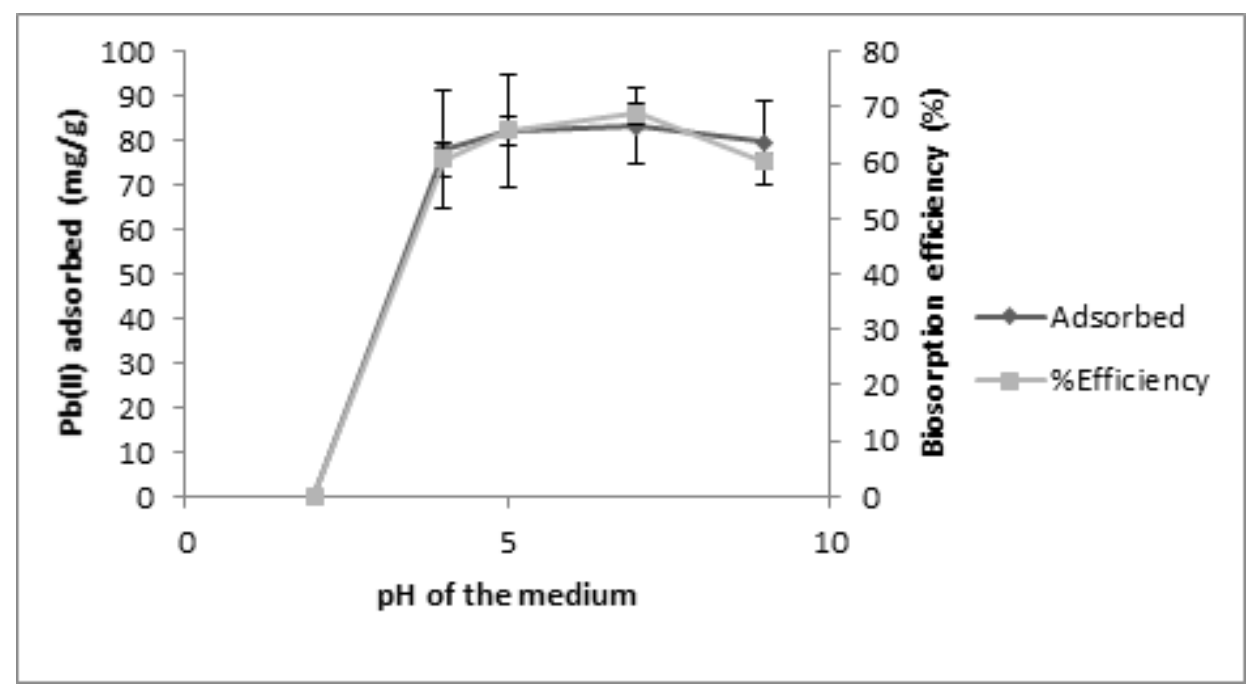

Figure 3: Lead (II) biosorption ( $\mathrm{mg} \mathrm{g}^{-1} \mathrm{~d}$.wt) and biosorption efficiency by Penicillium citrinum KR706304 at different $\mathrm{pH}$ values. Amount of dried biomass: $0.04 \mathrm{~g}$; initial metal concentration $\left(\mathrm{C}_{\mathrm{j}}\right): 50 \mathrm{mg} \mathrm{l}^{-1}$; suspension volume: $20 \mathrm{ml}$; temperature: $30^{\circ} \mathrm{C}$; agitation speed: $150 \mathrm{rpm}$. The data are the mean values of 3 replicates, and the bars indicate the standard deviation of the mean. 


\section{Effect of Temperature on Lead Biosorption}

The removal of lead by the isolated Penicillium citrinum KR706304 appears to be energy dependent biosorption, because it is affected by temperature. Although, the effects was not statistically significant $(p>0.05)$. Maximum lead removal was observed at $30{ }^{\circ} \mathrm{C}$ (Figure 4). This might be due to the physical damage towards the biosorbent expected at higher temperatures. The temperature of the biosorption medium could be important for energy dependent mechanisms in metal biosorption by microbial cells. Most of the time, biosorption is an exothermic process (Martins et al., 2006), but also, there are some examples of endothermic biosorption that have been reported (Davis et al., 2003; Ramasamy et al., 2011). During the endothermic biosorption processes, as in the case of this study, the extent of biosorption processes increases with increasing temperature up to the optimal level. This effect may be due to either higher affinity of binding sites for metal or more binding sites on relevant cell mass (Guo et al., 2006).

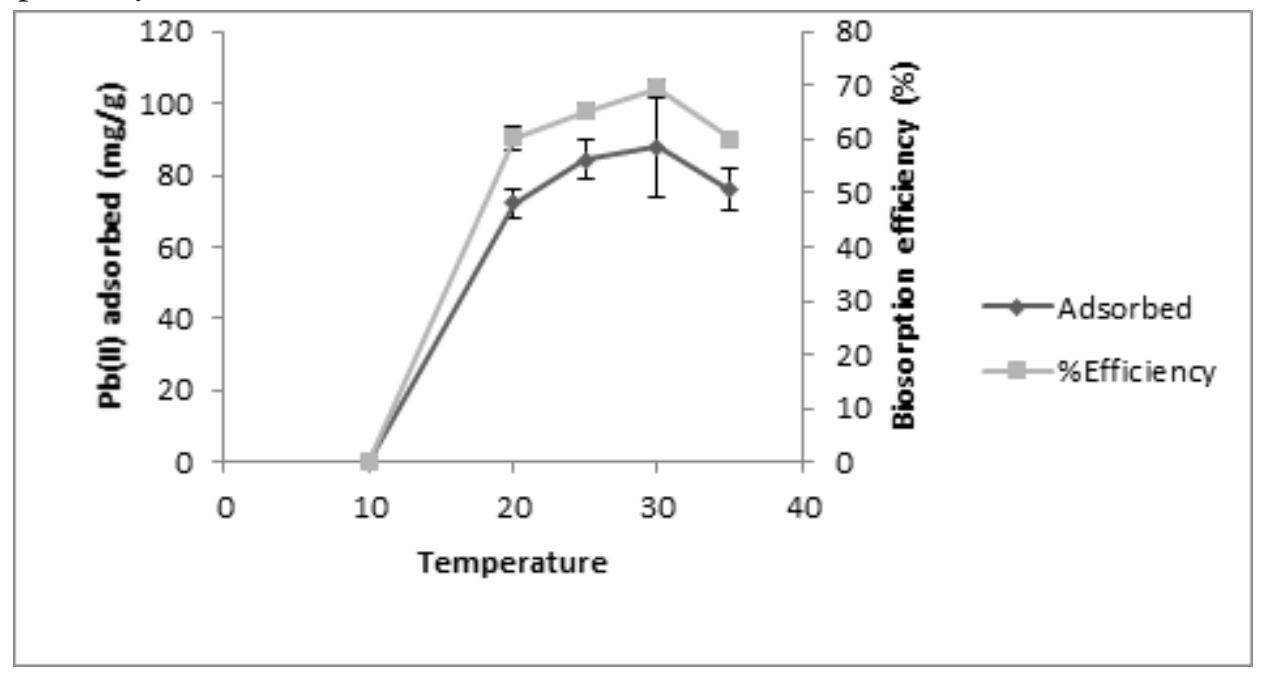

Figure 4: Lead (II) biosorption ( $\mathrm{mg} \mathrm{g}^{-1} \mathrm{~d}$.wt) and biosorption efficiency by Penicillium citrinum KR706304 at different temperature. Initial metal concentration $\left(\mathrm{C}_{\mathrm{i}}\right): 50 \mathrm{mg} \mathrm{l}^{-1}$; suspension volume: $20 \mathrm{ml}$; pH: 7; Amount of dried biomass: $0.04 \mathrm{~g}$; agitation speed: $150 \mathrm{rpm}$. The data are the mean values of 3 replicates, and the bars indicate the standard deviation of the mean.

\section{Effect of Initial Metal Concentration on Lead} Biosorption

The initial metal concentration is an important parameter in biosorption technology, which influences the adsorption of metal to the biomass surface. The results in this study indicated that lead(II) biosorption was increased with increasing lead(II) concentration of up to $400 \mathrm{mg} \mathrm{l}^{-1}$ by the isolated fungal strain (Figure 5). At lower initial concentrations, the ratio of initial number of metal ions to the available biosorption sites was low and higher biosorption efficiencies were obtained. In the case of higher initial concentrations, the available sites for biosorption became fewer and the saturation of the adsorption sites was observed. As a result the biosorption efficiencies decreased. This was obtained since initial metal concentration provides a driving force to overcome mass transfer resistances between the biosorbent and the biosorption medium (Dursun, 2006; Wahab et al., 2015). Similar results were reported for lead(II) biosorption by Pycnoporus sanguineus (Azila et al., 2008), and for lead(II) and $\mathrm{Cu}(\mathrm{II})$ by Aspergillus niger(Dursun, 2006). 


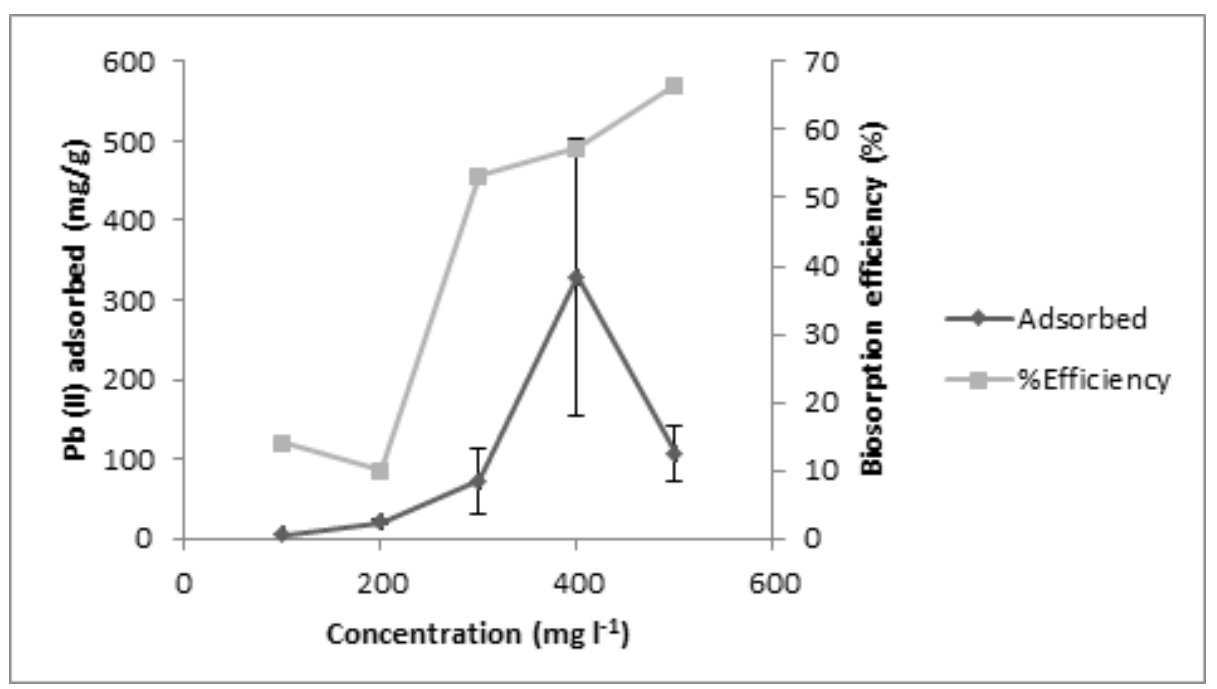

Figure 5: Lead (II) biosorption ( $\mathrm{mg} \mathrm{g}^{-1} \mathrm{~d}$.wt) and biosorption efficiency by Penicillium citrinum KR706304 at different initial concentration.Suspension volume: $20 \mathrm{ml}$; temperature: $30{ }^{\circ} \mathrm{C}$; $\mathrm{pH}$ : 7; agitation speed: $150 \mathrm{rpm}$. The data are the mean values of 3 replicates, and the bars indicate the standard deviation of the mean.

\section{Effect of Biomass Dose on Lead Biosorption}

The size of biosorbent used in biosorption studies is an important parameter which determined the capability of potential biosorbent to remove heavy metal ions such as lead(II) at a given initial dose. The results of this study indicated a significant effect of the biomass size on the biosorption process. Generally, the amount of lead(II) bioadsorbed per unit weight decreased with the increased amounts of biomass (Figure 6). Similar observations from previous studies had suggested decreased biosorption capacity at increased biosorbent dose to be influenced by electrostatic interaction and interference between binding sites (Tulani et al., 2006), and a partial aggregation of biomass at higher biomass doses, which in turn results in a decrease in effective surface area available for the biosorption (Karthikeyan et al., 2007). Romera et al. (2007) also, concluded that at higher biomass dose, biosorbent can exert a shell effect, which block the active sites from being occupied by metal.

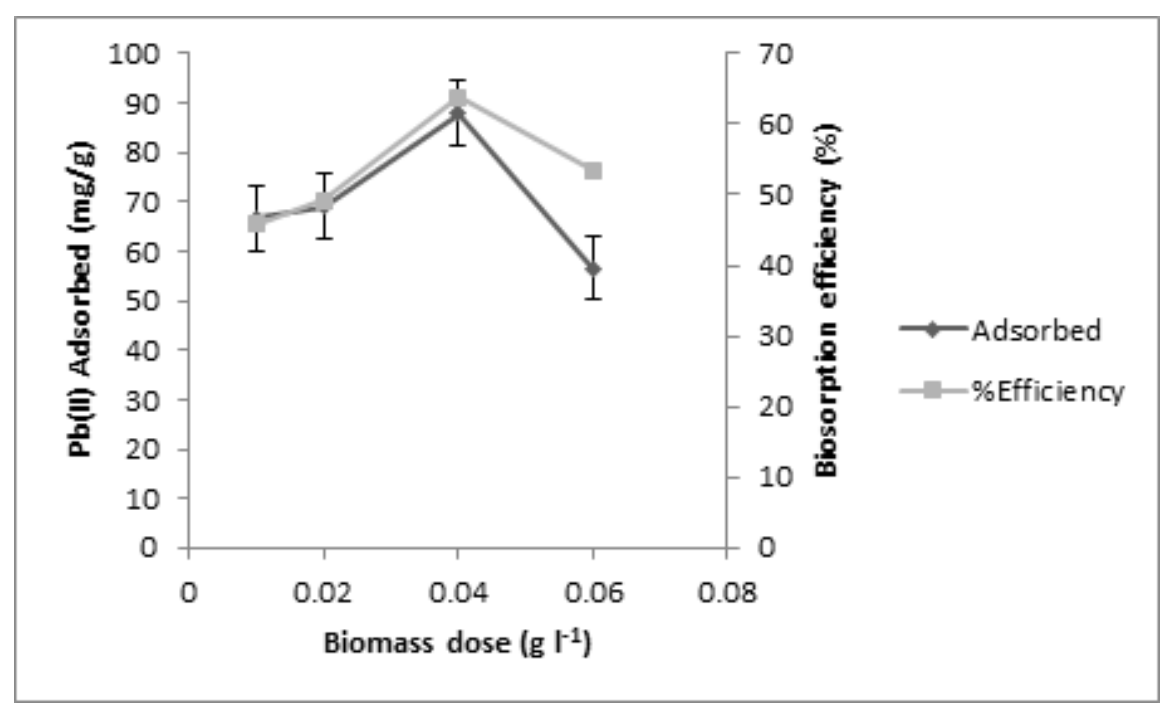

Fig. 6: Lead (II) biosorption ( $\mathrm{mg} \mathrm{g}^{-1} \mathrm{~d}$.wt) and biosorption efficiency by Penicillium citrinum KR706304 at different biomass dose. Initial metal concentration $\left(\mathrm{C}_{\mathrm{j}}\right): 50 \mathrm{mg} \mathrm{l}^{-1}$; suspension volume: $20 \mathrm{ml}$; temperature: $30{ }^{\circ} \mathrm{C} ; \mathrm{pH}$ : 7; agitation speed: $150 \mathrm{rpm}$. The data are the mean values of 3 replicates, and the bars indicate the standard deviation of the mean. 

Effect of Agitation Speed on Lead
Biosorption

The agitation speed was highest at $150 \mathrm{rpm}$ (Figure 7), similar to reports from previous studies, Cruz et al. (2004), reported that the biosorption of cadmium by Sargassum sp. was significantly affected by agitation speed and the maximum adsorption capacity was greater at 100 rpm. Cadmium(II) adsorption capacity by Aspergillus niger and chromium(VI) by Rhizopus nigricans (Bai and Abraham, 2001) were obtained at agitation speed of $120 \mathrm{rpm}$. Agitation provides the necessary contact between the metal ions in solution and the biomass binding sites, which in turn promotes effective transfer of metal ions to the biosorbent sites (Ahalya et al., 2005). The results obtained is in agreement with reports of Parvathi and Nagendran, (2007), and Abdulqawi, 2011, that the highest biosorption capacity of lead(II) at an agitation speed of $150 \mathrm{rpm}$ indicates least mass transfer resistance experienced by the system.

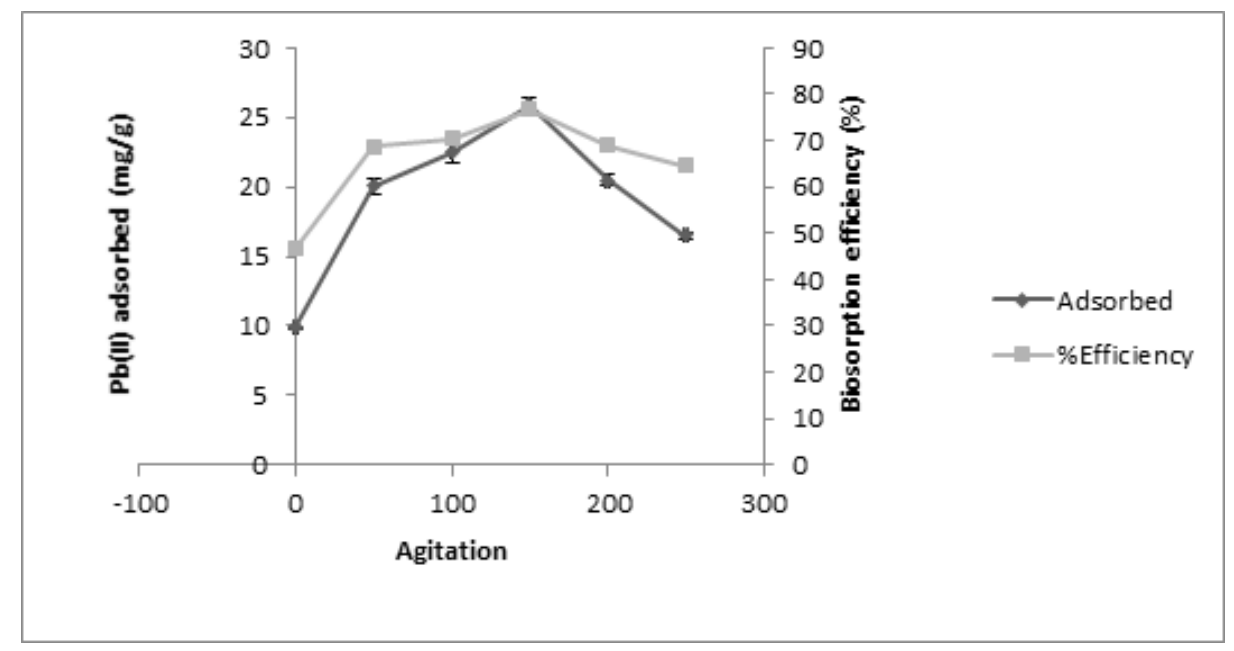

Figure 7: Lead(II) biosorption ( $\mathrm{mg} \mathrm{g}^{-1} \mathrm{~d}$.wt) and biosorption efficiency by Penicillium citrinum KR706304 at different agitation speed. Amount of dried biomass: $0.04 \mathrm{~g}$; initial metal concentration $\left(\mathrm{C}_{\mathrm{j}}\right): 50 \mathrm{mg}^{-1}$; suspension volume: $20 \mathrm{ml}$; temperature: $30^{\circ} \mathrm{C} ; \mathrm{pH}$ : 7. The data are the mean values of 3 replicates, and the bars indicate the standard deviation of the mean.

\section{Effect of Contact Time on Lead Biosorption} $\mathrm{Pb}(\mathrm{II})$ biosorption by the isolated Penicillium citrinum KR706304 reached an equilibrium at approximately $60 \mathrm{~min}$ (Figure 8). Biosorption was rapid in the first 30 min of contact time, which suggests the active interaction of metals with functional groups on the surface of the biomass. The observed biosorption kinetics has significant practical importance in biosorption of heavy metals on a large scale, as it will facilitate smaller reactor volumes that ensures efficiency and cost effectiveness (Herrero et al., 2005; Abdulqawi, 2011).

In addition, Li et al. (2008), reported a similar study on biosorption equilibrium of lead and copper ions by biomass of Penicillium simplicissimum, which reached equilibrium at $60 \mathrm{~min}$ of contact time. Biosorption processes depends on the functional groups on the cell surface and the nature of the metal ions (Engle and Kunz, 1995; Abdulqawi, 2011). It takes place in two stages; passive uptake which takes place immediately, and active uptake which takes place slowly (Goyal et al., 2003). The physical sorption is relatively a fast adsorption step. The rapid increase in the biosorption capacity during the initial stages of lead(II) biosorption observed in this study may be a physical adsorption, which can be categorized as extracellular sorption or surface binding. The chemical sorption or intracellular sorption is more of a metabolic process than the physical sorption (Lopez et al., 1995; Wahab et al., 2015). 


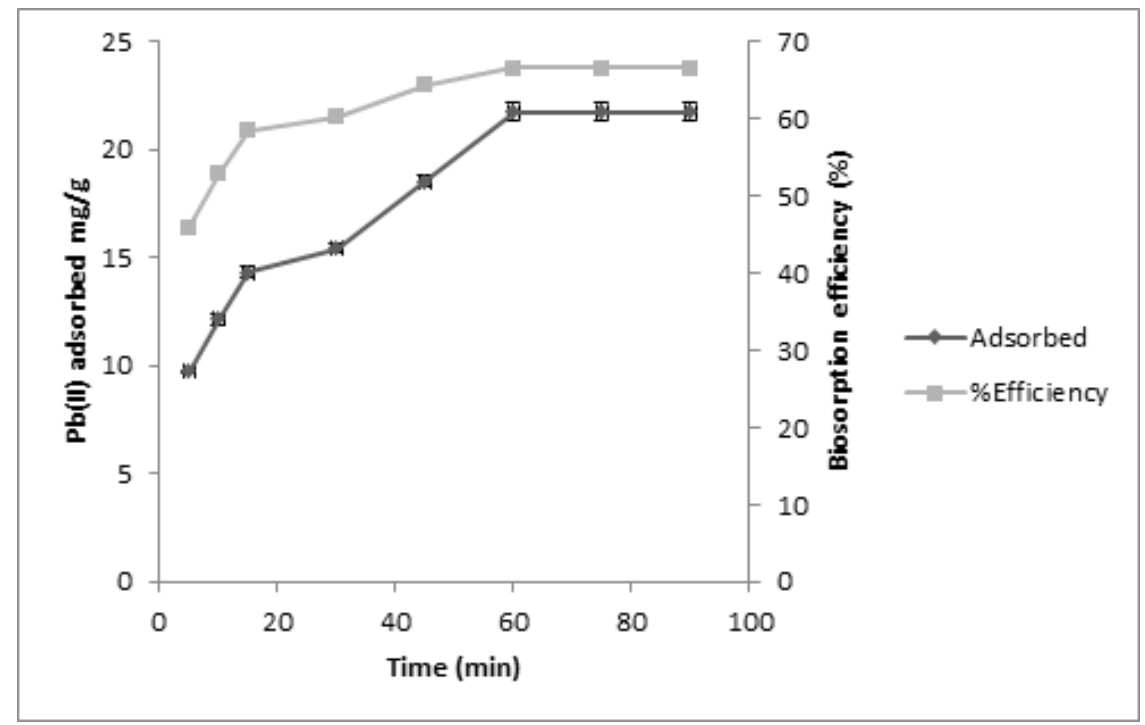

Figure 8: Lead(II) biosorption ( $\mathrm{mg} \mathrm{g}^{-1} \mathrm{~d}$.wt) and biosorption efficiency by Penicillium citrinum KR706304 at different time intervals. Amount of dried biomass: $0.04 \mathrm{~g}$; initial metal concentration $\left(\mathrm{C}_{\mathrm{i}}\right): 50 \mathrm{mg} \mathrm{l}^{-1}$; suspension volume: $20 \mathrm{ml}$; temperature: $30^{\circ} \mathrm{C}$; $\mathrm{pH}$ : 7 ; agitation speed: $150 \mathrm{rpm}$. The data are the mean values of 3 replicates, and the bars indicate the standard deviation of the mean.

\section{Effect of Biomass Age on Lead Biosorption}

The effect of biomass ages (ranging from 3-7 days) on the biosorption of lead(II) ions by the isolated fungal strains showed that younger cells had higher biosorption capacity than the older cells (Figure 9). It has been reported by Delgado et al. (1998), that in the biosorption of copper, cadmium and nickel by biomass of Fusarium flocciferum, older cultures showed a decrease in metal biosorption capacity. The observation in this study is also in agreement with the report of
Abdulqawi (2011), on biosorption of lead(II) and cobalt(II) ions by biomass of Rhizopus oryzae and Saccharomyces cerevisiae. During microbial growth, the cells at lag phase or early stage of growth were more active and possesses higher biosorption capacity for metal ions than that of stationary phase (Kapoor and Viraraghavan, 1997). Also, the percentage of chitin and chitosan in the fungal cell wall varies with the culture age and growth conditions (Zhou and Banks, 1993; Gharieb, 2002; Abdulqawi, 2011).

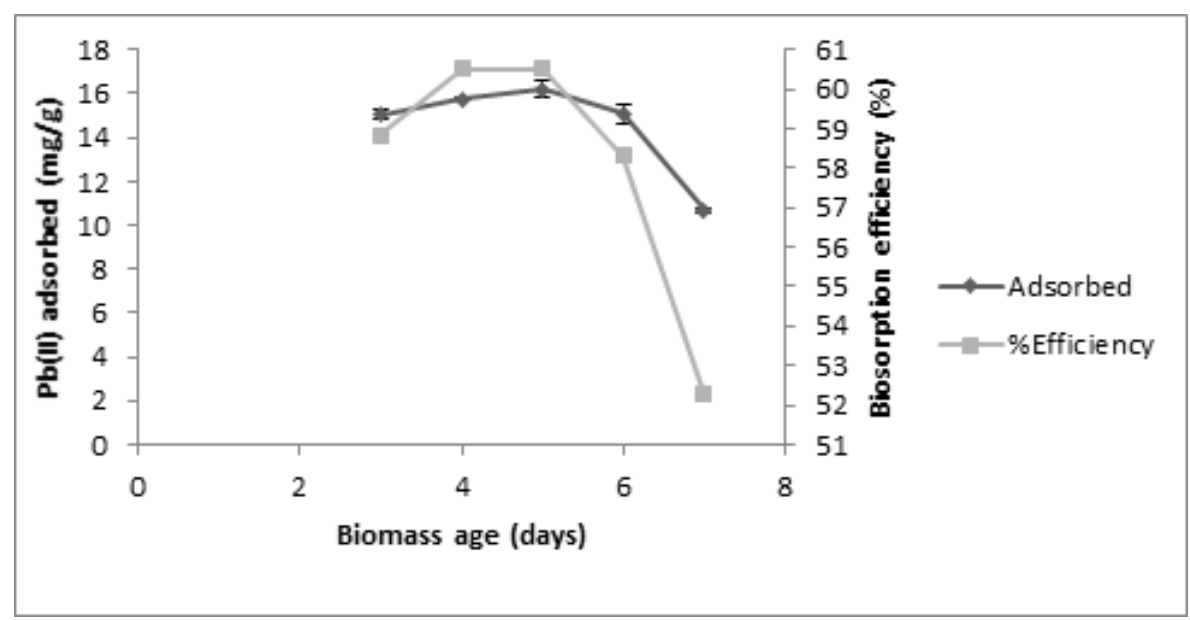

Figure 9: Lead(II) biosorption ( $\mathrm{mg} \mathrm{g}^{-1} \mathrm{~d}$.wt) and biosorption efficiency by Penicillium citrinum KR706304 biomass cultivated at different growth periods. Amount of dried biomass: $0.04 \mathrm{~g}$; initial metal concentration $\left(\mathrm{C}_{\mathrm{i}}\right): 50 \mathrm{mg} \mathrm{l}^{-1}$; suspension volume: $20 \mathrm{ml}$; temperature: $30^{\circ} \mathrm{C} ; \mathrm{pH}$ : 7 ; agitation speed: 150 $\mathrm{rpm}$. The data are the mean values of 3 replicates, and the bars indicate the standard deviation of the mean. 


\section{Scanning Electron Microscopy (SEM)}

The SEM micrographs observed for Penicillium citrinum KR706304 loaded with lead ions showed that the fungus could absorb lead from aqueous solutions to form insoluble lead precipitates within the matrix of fungal mycelia (Figure 10). The fungal mycelial morphologies of the outer surfaces were closely merged together in samples unloaded with heavy metals, while the outer surface network of the treated fungal mycelium became more porous and flexible, than in control. Natarajan et al. (2010), reported similar observations, and concluded that the physical strength of the treated mycelium was weaker under metal stress. The highly porous surface observed in the treated fungal mycelium favours the diffusion of metal ions into the cell, thereby leading to higher adsorption capacity (Zulkarnain et al., 2015).

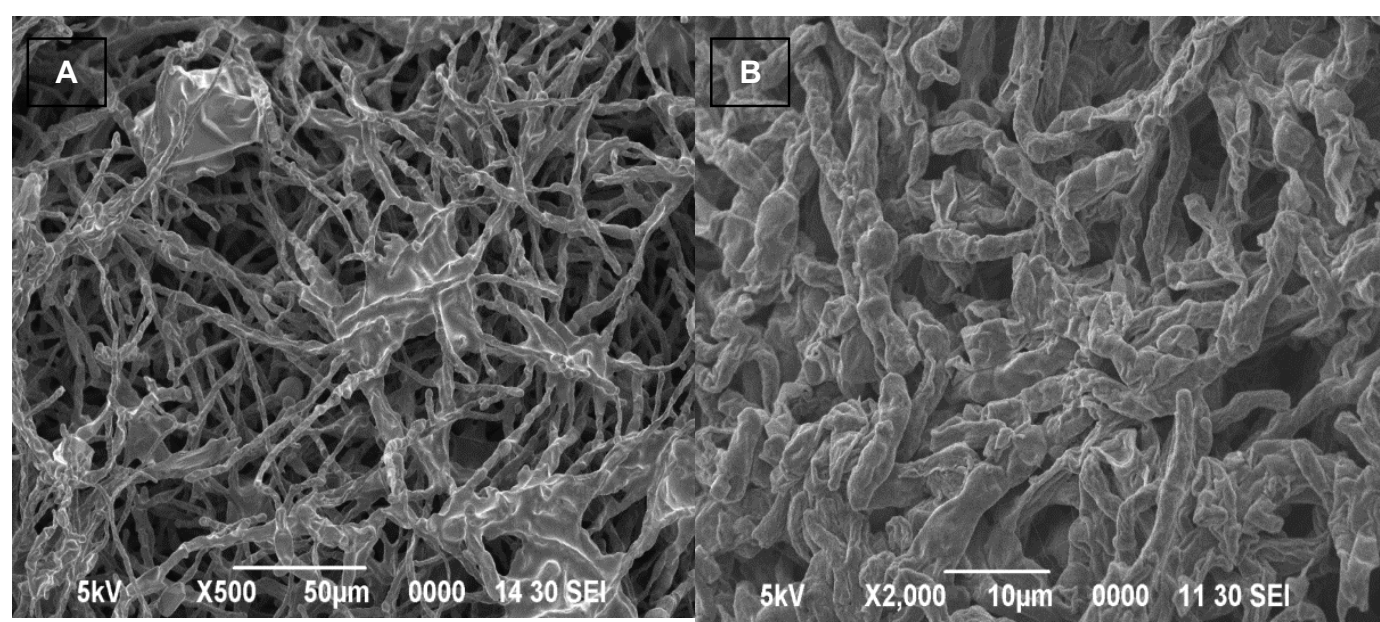

Figure 10: SEM micrographs of Penicillium citrinum KR706304 loaded with lead (A), and unloaded with metal (B).

\section{CONCLUSION}

The study demonstrated that the newly isolated metal resistant Penicillium citrinum KR706304 from mangrove soil environments has the potential application for the lead removal from aqueous solution.

\section{Conflict of interest}

There is no conflict of interest in this research work.

\section{ACKNOWLEDGEMENT}

This research was supported by Universiti Malaysia Sarawak and funded by Ministry of Education (MoE) under the Fundamental $\mathrm{R}$ e s e a r c h G a n t $\mathrm{Sch}$ e m e FRGS/2/10/SG/UNIMAS/02/03

\section{REFERENCES}

Abdulqawi, A (2011). Bioremediation of heavy metals from aqueous solutions by some fungi. In: Biosorption of lead and cobalt ions (Abdulqawi Al-Fakih, ed), pp 198201. LAP (Lambert Academic
Publishing), Germany.

Ahalya N, Kanamadi R.D, Ramachandra, T.V (2005). Biosorption of chromium (VI) from aqueous solutions by the husk of Bengal gram (Cicer arientinum). Electro. J. Biotechno. 8: 258-264.

Akar S., Akar T, Kaynak Z, Anilan B, Cabuk A, Tabak O, Demir, T.,A, Gedikbey T(2009). Removal of copper (II) ions from synthetic solution and real wastewater by the combined action of dried Trametes versicolor cells and montmorillonite. Hydrometallurgy. 97: 98-104.

Azila, Y.Y., Mashitah, M.D., Bhatia, S (2008). Process optimization studies of lead biosorption onto immobilized cells of Pycnoporus sanguineus using response methodology. Bioresour. Technol. 99: 85498552.

Bai, R.S, and Abraham, T.E (2001). Biosorption of $\mathrm{Cr}(\mathrm{VI})$ from aqueous solution by Rhiropus nigricans. Biores. Technol. 79: 73-81.

Baysal, Z., Cinar, E., Bulut, Y, Alkan, H., Dogru, M (2009). Equilibrium and 
thermodynamic studies on biosorption of $\mathrm{Pb}(\mathrm{II})$ onto Candida albicans biomass. J. Hazardous. Material. 161, 62-67.

Bennett, R.M., Cordero, P.R.F., Bautista, G.S and Dedeles, G.R (2013). Reduction of hexavalent chromium using bacteria and fungi isolated from contaminated soil and water samples. Chemistry and Ecology, 29 (4), 320-328.

Chen, X.C., Shi, J., Chen, Y, Xu, X., Chen, L., Wang, $\mathrm{H}$ and $\mathrm{Hu}, \mathrm{T}(2007)$. Determination of copper binding in Pseudomonas putida CZ1 by Chemical Modifications and X-Ray Absorption Spectroscopy. Applied Microbiology and Biotechnology. 74: 881-889.

Cruz, C.C.V., da Costa, A.C.A., Henriques, C.A., Luna, A.S (2004). Kinetic modeling and equilibrium studies during cadmium biosorption by dead Sargassum sp. biomass. Bioresour. Technol. 91:249-257.

Davis, T.A., Volesky, B., Mucci, A (2003). A review of the biochemistry of heavy metal biosorption by brown algae.Water Resour. 37: 4311-4330

Delgado, A., Anselmo, A.M., Novais, J.M (1998). Heavy metal biosorption by dead powdered mycelium of Fusarium flocciferum. Water Environ Research. 70: 370375.

De Sotto, R., Monsanto, R. Z., Edora, J.L., Bautista, R.H., Bennett, R.M, and Dedeles, G.R (2015). Reduction of $\mathrm{Cr}$ (VI) using indigenous Aspergillus spp. isolated from heavy metal contaminated sites.

Dursun, A.Y (2006). A comparative study on determination of the equilibrium, kinetic and thermodynamic parameters of biosorption of copper(II) and lead(II) ions onto pretreated Aspergillus niger. Biochem. Eng.J. 28:187-195.

Engle, A., Kunz, B (1995). Biosorptionof heavy metals by Saccharomyces cerevisiae-effect of nutrients conditions. J. Chem. Technol. \& Biotechnol. 63: 257-261.

Gharieb, M.M (2002). Biosorption and solubilization of copper oxychloride fungicide by Aspergillusniger and the influence of calcium. Biodegradation. 13: 191-199.
Goyal, N., Jain, S.C., Banerjee, U.C (2003).Comparative studies on the microbial adsorption of heavy metals. Advances in Environ. Research. 7:311-319.

Guo, L.Y., Ting, F., Ming, Z.G., Xin, L., Qing, T., Fei, Y., Ming, Z., Hua, X.W., Yue, H (2006). Removal of cadmium and zinc ions from aqueous solution by living Aspergillus niger. Transactions of Non-ferrous Metals Society of China. 16: 681-686.

Gupta, R., Saxena, R.K., Mohapatra, H., Ahuja, P (2002). Microbial variables for bioremediation of heavy metals from industrial effluents. In: Biotransformations: Bioremediation Technology for Health and Environmental Protection. Vol. 36 (Singh, V.P. \& Stapleton, R.D. Jr. Eds). Pp. 189-229. Amsterdam, Netherlands. Elsevier.

Herrero, R., Lodeiro, P., Castro, C.R., Vilarino, T., Sastre de Vicente, M.E (2005). Removal of inorganic mercury from aqueous solutions by biomass of the marine macroalga Cystoseira baccata. Water Research. 39:3199-3210.

Iskandar, N.L., Zainudin, N.A., Tan, S.G (2011). Tolerance and biosorption of copper $(\mathrm{Cu})$ and lead $(\mathrm{Pb})$ by filamentous fungi isolated from a freshwater ecosystem. J. Environ. Sci. 23(5): 824-830.

Kapoor, A., and Viraraghavan, T (1997). Fungi as biosorbents. In: Biosorbents for Metal Ions (Wase, J. \& Forster, C., Eds.). pp.67-85. London, UK: Taylor \& Francis.

Karthikeyan, S., Balasubramanian, R., Iyer, C.S.P (2007). Evaluation of the marine algae Ulva fasciata and Sargassum sp. for the biosorption of $\mathrm{Cu}(\mathrm{II})$ from aqueous solution. Bioresour. Technol. 98: 452-455.

Kumar, M.A., Vijayalakshmi, A., Lincy, E.A.R (2014). Biotransformation of reactive black HEBL into 3 nitroso-3-azabicyclo $(3,2,2)$ nonane by an acclimated mixed culture. International journal of ChemTech Research.6(9): 4172-4179.

Lopez, F.A., Perez, C., Sainz, E., Alonso, M (1995). Adsorption of $\mathrm{Pb}^{2+}$ on blast furnace sludge.J. Chem. Technol. Biotechnol. 62:200-206.

Li, X.M., Liao, D.X., Xu, X.Q., Yang, Q, (2008). Kinetic studies for the biosorption of lead and copper ions by Penicillium 
simplicissimum immobilized within loofa sponge. J. Hazardous. Material. 159: 610615.

Martins, B.L., Cruz, C.C.V., Luna, A.S., Henriques, C.A (2006). Sorption and desorption of $\mathrm{Pb}^{2+}$ ions by dead Sargassum sp. Biomass. Biochem. Eng. J. 27: 310-314.

Mason, L.H., Harp, J.P and Han, D.Y (2014). Pb neurotoxicity: neuropsychological effects of lead toxicity. BioMed Research International. 2014. Article ID 840547, 8 pages.

Muñoz, A.J., Espinola, F., Moya, M., and Ruiz, E (2015). Biosorption of $\mathrm{Pb}(\mathrm{II})$ ions by Klebsiella sp. $3 \mathrm{~S} 1$ isolated from a wastewater treatment plant; kinetics and mechanisms studies. BioMed Research International, 2015.

Natarajan, V., Grim, H., Muthuswamy, S., Tae, K.C., Kui-Jae, L., Byung-Taek, O., YangSoo, L (2010). Isolation, identification, $\mathrm{Pb}$ (II) biosorption isotherms and kinetics of a lead adsorbing Penicillium sp. MRF-1 from South Korean mine soil. J. Environ. Sci. 22(7): 1049-1056.

Parvathi, K and Nagendran, R (2007). Biosorption of chromium from effluent generated in chrome-electroplating unit using Saccharomyces cerevisiae. Separation Science Technol. 42: 625-638.

Ramasamy, R., Kumar, C. S., Thamariaselvi, K (2011). Evaluation of isolated fungal strain from e-waste recycling facility for effective sorption of toxic heavy metal $\mathrm{Pb}$ (II) ions and fungal protein molecular characterization- a mycoremediation approach. Asian J. Experimental Biol. Sci. 2(2): 342-347.

Romera, E., Gonzalez, F., Ballester, A., Blazquez, M.L., Munoz, J.A (2007). Comparative study of biosorption of heavy metals using different types of algae. Bioresour. Technol. 98: 3344-3353.

Sana, S., Roostaazad, R., and Yaghmaei, S (2015). Biosorption of Uranium (VI) from Aqueous Solution by Pretreated Aspergillus niger using Sodium Hydroxide. Iranian Journal of Chemistry and Chemical Engineering, 34(1), 65-74.
Sari, A. and Tuzen, M. (2009). Kinetic and equiliubrium studies of biosorption of $(\mathrm{Pb}(\mathrm{II})$ and $\mathrm{Cd}(\mid \mathrm{II})$ from aqueous solution by macrofungus (Amanitaru bescens) biomass. Journal of Hazardous Materials, 164, 1004-1011

Say, R., Yilmaz, N., Denizli, A (2003). Biosorption of cadmium, lead, mercury, and arsenic ions by the fungus Penicillium purpurogenum. Separation Science Technol. 38: 2039-2053.

Say, R., Denizl, A., Arica, M.Y (2011). Biosorption of $\mathrm{Cd}(\mathrm{II}), \mathrm{Pb}(\mathrm{II})$ and $\mathrm{Cu}(\mathrm{II})$ with the filamentous fungus Phanerochaete chrysosporium. Bioresource Technol. 76(1): 6770.

Subhashini, S.S., Velan, M., Kaliappan, S (2013). Biosorption of lead by Kluyveromyces marxianus immobilized in alginate beads. J. Envirol. Biol. 34: 831-835.

Tulani, S., Akar, T., Ozcan, A.S., Kiran, I., Ozcan, A (2006). Equilibrium and kinetics of biosorption of lead (II) from aqueous solutions by Cephalosporium aphidocola. Separation and Purification Technol. 47: 105112.

Volesky, B (2007). "biosorption and me" Water Research. 41(18): 4017-4029.

Wahab, A.A., Awang, A.A.S., Azham, Z., Tay, M.G., Hairul, A.R (2015). Factors affecting toxic lead (II) ion bioremediation by Fusarium equiseti isolated from mangrove soil environment of Southeast Borneo. Mal. J. Microbiol. 11(special issue): 215-222.

Wang, J and Chen, C (2006). Biosorption of heavy metals by Saccharomyces cerevisiae: a review. Biochemistry Advances, 24, 427-451.

Zhou, J.L. and Banks, C.J (1993). Mechanism of humic acid colour removal from natural waters by fungal biomass biosorption. Chemosphere, 27: 607-620.

Zulkarnain, C., Shinta, J., Rahmiana, Z., Edison, M (2015). Biosorption of $\mathrm{Cd}(\mathrm{II})$ from aqueous solution using living and nonliving Microalga Scenedesmus dimorphus. Research J. Pharm. Biol. Chem. Sci. 6(2): 1972-1980. 